\title{
HOW IS ROBERT JENSON TELLING THE STORY?
}

\author{
Anné H Verhoef \\ Department of Systematic Theology and Ecclesiology \\ Stellenbosch University
}

\begin{abstract}
This essay focuses on how the well-known Lutheran theologian Robert Jenson is telling the Christian story. It gives an introduction on Robert Jenson as a person and then shows how his theology can be summarised with reference to three interrelated themes, namely: Trinity, Time and Church. Jenson is a trinitarian theologian. In his understanding that cannot be separated from being a narrative theologian. According to him, the Christian story is a story of hope and its eschatology must be able to survive any criticism - such as the Marxist and the ecological ones. If Jenson thus asks how the End will be, he does not see it as a repristination of the beginning, but as a sublimation - our end is inclusion in God's life. The article concludes his sort of 'theology of hope' is one that can help Christians against the threat of nihilism.
\end{abstract}

Key Words: Robert Jenson, Church, Time, Trinity

\section{Introduction}

To answer the question of how Robert Jenson is telling the story, is a challenging task because of the style and complexity of Jenson's theology. In this essay I will nevertheless attempt to give an indication of the main thread of the storyline in his theology. I will start by giving an introduction to Jenson as theologian and to his major theological works. The main themes of his theology will immediately become apparent. In the next part of the essay I will focus on the fact that Jenson is indeed telling a story in his theology and that this story is for Jenson a story of hope. Because it is a story of hope, the focus in the story is very much on eschatology. The question of how Jenson understands the end will thus be important to investigate. In the last part of the essay I will look at Jenson's proposal to name the Trinity specifically as the God of hope. I will ask the question whether there are any alternatives to God being a God of hope.

It is impossible to summarize Jenson's theology - or the way in which he tells the story - in this one essay. His theology is too comprehensive and he works out all his major points to very small detail. An overview of his theology will thus necessarily do injustice to all his accents, and has the danger to focus only on fragments and not on the whole theological system. ${ }^{1}$ In an attempt to overcome this problem I will make use of an article of Jenson himself, with the title 'Second Thoughts about Theologies of Hope' (Jenson 2000b), in which he summarizes important aspects of his theology. Because of the title of this essay I will focus more on Jenson's theology as a narrative theology. It will become apparent that his theology can be described as a trinitarian narrative and an ecumenical theology - and of course an eschatological theology.

Jenson (1997a:18) himself said in this regard: "It is the fate of every theological system to be dismembered and have its fragments bandied about in an ongoing debate." 


\section{Robert Jenson's Theology}

Robert William Jenson is 'the' American Lutheran theologian. He was born in 1930 in Eau Claire, Wisconsin, in the US. He was senior scholar for research at the Centre of Theological Inquiry in Princeton, New Jersey from 1998 and has recently retired. ${ }^{2}$ Jenson studied and worked in Germany, the United Kingdom and in the United States. ${ }^{3}$ Although Jenson is sometimes described as an American theologian, he is well known and respected internationally as a theologian. In the book Trinity, Time, and Church: A Response to the Theology of Robert $W$ Jenson (edited by Gunton 2000), theologians from all over the world and from many different denominations contributed essays of appreciation and dialogue with Jenson's theology.

Jenson was and still is a very productive theologian. He wrote extensively throughout his career and among his many books are the two volumes of his Systematic Theology Volume 1: The Triune God (1997) and Volume 2: The Works of God (1999). ${ }^{4}$ Some of his earlier books include his main dogmatic works: God after God: The God of the Past and the God of the Future, Seen in the Work of Karl Barth (1969), the short and popular Story and Promise: A Brief Theology of the Gospel about Jesus (1973), the more comprehensive Triune Identity: God according to the Gospel (1982), and a collection of theological themes published with Carl Braaten in Christian Dogmatics (1984). ${ }^{5}$

His later works include A Map of Twentieth Century Theology. Readings from Karl Barth to Radical Pluralism (1995, with Braaten) and his excellent analytical book: On Thinking the Human: Resolutions of Difficult Notions (2003). His more ecumenical focused books were also written later in his life and include: Unbaptized God The Basic flaw in Ecumenical Theology (1992), Jews and Christians (2003, with Braaten), In One Body through the Cross (2003, with Braaten), and The Ecumenical Future (2004, with Braaten).

Jenson also wrote analytical books about the culture of the day and most of these were written with his colleague Carl Braaten. These include Either/Or. The Gospel or Neopaganism (1995), Essays in Theology and Culture (1995), Sin, Death, \& the Devil (2000), and The strange New Word of the Gospel. Re-Evangelizing in the Postmodern World

2 He was the cofounder and associate director of the Centre for Catholic and Evangelical Theology (founded in 1991) and also the cofounder and co-editor of Pro Ecclesia the Centre's journal.

3 In Germany he studied at the University of Heidelberg where he received his doctoral degree in theology in 1960. He began his studies at Luther Seminary in St. Paul, Minnesota in 1951. This was where he began his academic life as lecturer as well. From 1961 to 1966 he was the Professor of Philosophy and Chairman of Philosophy Department at Luther College. From 1966 to 1968 and again from 1972 to 1973 he was the Lutheran World Federation Lecturer in Theology at Oxford University in the United Kingdom. During this time and afterwards (1968-1988) he was also the Professor of Systematic Theology at the Lutheran

Theological Seminary, Gettysburg, PA. From 1988 to 1998 he was Professor of Religion at St. Olaf College, Northfield, MN. His last position was as Senior Scholar for Research (1998-2003) at the Centre of Theological Inquiry, Princeton, NJ.

4 Jenson agrees with contemporary theologians that the work of God may be understood as a narrative, but in his Systematic Theology he does not follow the traditional themes in a chronological order, for example: 1) creation, 2) history, 3) sin, 4) providence, 5) redemption, 6) church and 7) completion (eschatology). Jenson chooses to follow a structure to accommodate both Catholic and Protestant models and have seven parts (main themes) in the two volumes: The Triune Identity (Vol 1) 1) Prolegomena, 2) The Triune Identity, 3) The Triune Character, and in The Works of God (Vol 2) 4) The Creation, 5) The Creatures, 6) The Church and 7) The Fulfillment. It is clear (already from the structuring of his theology) that Jenson first identifies who God is (the trinitarian God) and then discuss His works. He does discuss the traditional themes, but it is not possible to separate it from his discussion about who God is. Andrew Burgess (2004:163) says in this regard: "Due to Jenson's complex analysis, it is remarkably difficult to treat any one theological theme in isolation from his compendious reworking of theology as a whole, and in particular from his doctrine of the Trinity."

5 The book Christian Dogmatics (1984) was written with his colleague Carl Braaten. Jenson wrote the chapters on the Trinity, the Holy Spirit and the Sacraments. 
(2002). They also wrote more popular books such as The two cities of God: The church's responsibility for the earthly city (1995), Reclaiming the Bible for the Church (1995) and The Catholicity of the Reformation (1996). ${ }^{6}$

Jenson did his doctoral studies under Peter Brunner in Heidelberg on the theology of Karl Barth. His first book in 1963 was a revised edition of his doctoral thesis with the title Alpha and Omega, A Study in the Theology of Karl Barth. This was the first of many books and articles on Barth's theology. ${ }^{7}$ About Barth and trinitarianism Jenson (1989:46) writes: "Finally, in Barth himself the theological incorporation of all these dynamics is a decisively trinitarian theology, after centuries in which trinitarianism was in Western reflection a problem rather than a resource. It can fairly be said that the chief ecumenical enterprise of current theology is rediscovery and development of the doctrine of Trinity. It can also fairly be said that Barth initiated the enterprise." In many ways Jenson's own theology is a continuation of Barth's theology - especially in its focus on trinitarianism. Kendall Soulen (1999:35) wrote for example in his article 'YHWH the Triune God', that Karl Barth is the father of the modern trinitarian revival and that "Robert Jenson (is) perhaps the major trinitarian theologian writing in English today." But Jenson also differs from Barth in his theology and also gave illuminating criticism. Colin Gunton (1995:948) for example also wrote about Jenson: "A feature shared by Rahner and his Protestant counterparts is a suspicion of speculation about the inner and eternal being of God. This is particularly apparent in the American Lutheran, Robert W Jenson, whose chief criticism of Barth, about whose trinitarian theology he has written extensively (Jenson 1963, 1969), is that he does not take far enough the criticism of 'religion' that is for him one of the main functions of trinitarian theology."

As mentioned earlier, Jenson's own theology can be summarised in three interrelated themes, namely: Trinity, Time and Church (or ecumenism). ${ }^{8}$ In his exploration of the Trinity he mainly differs from Barth's understanding of the relationship between time and eternity and Trinity (see Alpha and Omega. 1963, 1969). ${ }^{9}$ He then starts to construct his

6 This is only some of the best-known books of Jenson. The bibliography has more details on these books, but for a more comprehensive list of the writings of Jenson see: Bibliography (compiled by Jeremy GA Ive) in: Gunton, CE (ed.) 2000. Trinity, Time, and Church. A Response to the Theology of Robert W Jenson. (Grand Rapids: WB Eerdmans), 312-322. Unfortunately this bibliography of Ive was compiled in 2000 and after that Jenson published many more books and articles. A list of these is available in my unpublished thesis entitled Alfa en Omega: ' $n$ Studie in die trinitariese denke van Robert Jenson, (2008) University of Stellenbosch.

7 In 1969 Jenson published a further study on the theology of Barth under the title: God after God: The God of the Past and the God of the Future, Seen in the Work of Karl Barth. Jenson also wrote the discussion about Barth's theology in his and Braaten's book: A Map of Twentieth Century Theology: Readings from Karl Barth to Radical Pluralism (1995, with Braaten). And in the influential and authoritative The Modern Theologians (Ford 1989) Jenson also wrote the chapter on Barth's theology.

8 This is also the title of Gunton's book about the theology of Jenson: Trinity, Time, and Church: A Response to the Theology of Robert W Jenson (2000).

I chose ecumenism (and not church) here, because Jenson (1997a: viii) himself says of his own theology that it is done in 'anticipation of the one church.' In other words, his Ecclesiology is consistently written with an ecumenical aim. Philip Cary (1999:133) wrote very appreciative of Jenson's aim in this regard: “Arguably the most beautiful and important theology of our time is being develop between the various churches, in ecumenical discussions which elucidate the structure of thought and practice common to all the particular Christian traditions. Robert Jenson's recent work is situated in that between, inhabiting the common space of ecumenical theology and examining its problems. The solutions he proposes are bold and innovative, often idiosyncratic and unlikely to be widely accepted yet instructive and immensely suggestive to anyone who thinks theology should solve its problems not by conforming to the agendas set by the world (modernity, post modernity, or any other age) but by renewing its attention to the Gospel of Christ."

9 Jenson (1997a:217) writes in his Systematic Theology: "Yet there is something Barth did not say that must be said, and with emphasis. Simply that source and goal are real in God would not make his eternity a 'duration,' 
own understanding and from that starting point he undertakes many revisions in the doctrine of the Trinity (see Story and Promise: A Brief Theology of the Gospel about Jesus, 1973; and Triune Identity: God According to the Gospel, 1982). ${ }^{10}$ The implications of this are far reaching for the church as Jenson explores mainly the ecumenical benefits of his proposals in his theology (see Unbaptized God: The Basic flaw in Ecumenical Theology, 1992). ${ }^{11}$ Brian Sholl's (2002:27) comment is very illuminating: “...the kinds of thought he [Jenson] opposes in constructing his theology can be taken as clues: an Aristotelian grammar of substance, the Platonic distinction between being and becoming, and, most importantly, the distinction between time and eternity. Since Jenson frames his critique of the time/eternity distinctions in terms of a critique of divine impassibility, many of the revisions undertaken concern the doctrine of the Trinity. Famously, Jenson envisages trinitarian relations as constitutive of the human experience of time while exceeding those structures by means of a divine infinity."

In his focus on the relationship between time and Trinity Jenson develops his own theology as a narrative theology (see Story and Promise: A Brief Theology of the Gospel about Jesus, 1973). The Finnish Lutheran theologian, Tuomo Mannermaa, discusses this aspect of Jenson's theology and says that Jenson's theology can therefore be characterised as trinitarian and as narrative. Mannermaa (2000:140) writes:

One of the main themes in his [Jenson's] work is his criticism of the Denkform of 'Mediterranean antiquity.' According to this false Denkform, eternity and time are contradictory realities. "The relation of eternity to time was grasped by mere negation" (Jenson 1997a:94). Jenson says that in this discourse, “... deity is a quality, which may be analyzed as immunity to time plus whatever are its necessary conditions" (Jenson 1997a:94). God was defined with time-denying predicates such as 'immutability' and, centrally, 'impassibility,' that is, immunity to suffering and temporal-historical

a temporal infinity. He is temporally infinite because 'source' and 'goal' are present and asymmetrical in him, because he is primally future to himself and only thereupon past and present for himself. It is in that he is Spirit that the true God avoids so to speak the timelessness of mere form or mere consciousness."

He then explains his understanding of the poles of time and the Trinity: "We may begin by noting the connection between the poles of time and the mutual triune roles of Father, Son, and Holy Spirit. That this connection has often been the occasion of modalist puerilities must not prevent us from reckoning with it. The Father is the 'whence' of God's life; the Spirit is the 'whither' of God's life; and we may even say that the Son is that life's specious present" (Jenson 1997a:218-219).

10 Gerhard Forde (2000:127), for example, writes about the importance of the relation between time, eternity and Trinity in Jenson's theology: "Thus battle between time and eternity becomes the hallmark of Jenson's theology. There is a constant polemic throughout his work against the 'timeless' God of the Greeks. Virtually every theological 'sin' and false formulation can be traced to the intrusion of such timelessness into the theological scene."

Yeago (1992:18) adds to this: “All of Jenson's theological work is ordered around a central polemical axis: the conflict between 'the gospel about Jesus' and the assumptions of what Jenson in recent years tends to call 'normal religion.' In this, he is self-consciously the heir of the dialectical theology of the 1920's, specifically of the problematic so vividly and violently propounded in the second edition of Barth's Romans."

11 Paul Carey (1999:133) offers a helpful perspective on Jenson in this regard: "Jenson traces the problems which structure (and fracture) today's ecumenical theology to this most decisive conversation of the Christian tradition. The religious understanding of ancient mediterranean Gentiles became an articulate theology in the writings of Greek philosophers, whose concept of the divine as timeless eternity was the most powerful rival to Jewish and Christian conceptions of God as historical redeemer. In locus after locus, Jenson's solutions to the problems of ecumenical theology involve uncovering an undigested nugget of philosophical timelessness (often operating as a hidden assumption common to both sides in a theological dispute) and suggesting ways to complete the evangelization the fathers started."

In Jenson's book, Unbaptized God, he argues that Christian theology took over a Hellenistic divinity without 'baptizing' it. With that he means that God's impassibility was not overcome in Christian theology and that lead to ecumenical dividedness. 
contingency in general. According to Jenson, the assimilation of this Denkform of Mediterranean antiquity has been a great disaster for the history of Christian theology. For him, the real presence of God in human history, his 'historicity' and 'passibility,' are decisive. It can be said that Jenson's own Denkform has very close relation indeed with the Lutheran maxim finitum capax infiniti. For Jenson, as for Luther, the concrete reality of the historical Jesus and the whole narrative of God's history with mankind (Heilsgeschichte) are the foundation on which a theological ontology as Trinitarian ontology must be conceptualized.

The connection between trinitarian theology and narrative theology is very clear in Jenson's work. ${ }^{12}$ Jenson (1997a:150) says for example "It is the ... function of trinitarian propositions to say that the relations that appear in biblical narrative between Father, Son and Spirit are the truth about God himself." Ted Peters (1998:342-343) says that Jenson must be understood as a narrative theologian: “Jenson's emphasis on the historical particularity of God's identity makes him a narrative theologian with an attitude. God's story takes on an ontological status - that is, the story of Jesus of Nazareth and the story of the Holy Spirit's presence in the church belong to the very being of God. God is not God without his story. What identifies God as Trinity is not some abstract debate regarding how three can be one or one can be three. Rather, God is Trinity because this historical involvement as Son and as Spirit belongs essentially to the life of the one God."

\section{Robert Jenson is indeed telling the Story}

So we must say at this point - before we ask the question 'how' in more detail - that Robert Jenson is indeed telling the story. About the importance of telling this story Jenson (2000a:17) wrote in an article: "What is to be done within the church and synagogue seems relatively plain. God's people must gather the courage to subordinate other narratives to their own, to proclaim and live within a metanarrative that is 'meta' in superlative degree. If the story the Bible tells, running from creation to consummation and plotted by Exodus or Exodus-Resurrection, is true, it is not just our story but God's. If it is God's story, it is universal. And if it is the triune God's story, it cannot be oppressive."

The way in which Jenson tells the story (of God) always involves the trinitarian God. He adopts the rule of Karl Rahner in which the immanent Trinity is the economic Trinity and vice versa. This means that: "God's external relations to the world provide the very arena in which God's internal relations take place. That is, historical events such as Jesus praying to the Father or the Father abandoning the crucified Jesus to death constitute the very relations of the first two persons of the Trinity; they do not merely mirror in time some other relations taking place in separated eternity" (Peters 1998:342).

Jenson also follows the trinitarian theologians in emphasizing the eschatological character of scripture's witness to God. For Jenson, eternity is not timelessness, "but God's inexhaustible ability to anticipate the future. The story of God, then, is to be interpreted primarily from the eschatos, and not merely from the arche, as has traditionally been done" (Mattes 2000:467-468). In his strong eschatology he accepts Pannenberg's point of view,

12 Jenson says for example about his Systematic Theology (vol 1): "Moreover, we may take this observation as a key to the whole book: this Gospel explicitly recounts the simultaneous and identical course of Jesus' life in Israel with his disciples and his life with the Father as the Son. So read, this Gospel has been a chief New Testament inspiration of developed trinitarian doctrine. Read otherwise, it always resists coherent interpretation" (1997a:93).

13 The title of this article, "Can we have a story?", shows something of Jenson's plea and insistence for a narrative theology. Jenson develops the same arguments in his book on this topic, Story and Promise: A Brief Theology of the Gospel about Jesus (1973). 
but is critical towards others: "Barth and similarly Bultmann related the Bible's futurist eschatology to the present by concentrating on the reality of God which is its constituting heart. But in the process they stripped it of its specific temporal structure, its drive toward fulfilment" (Jenson 1999:309-310). Jenson proposes in a very ecumenical spirit (but leaning towards the Eastern Orthodox tradition) that "the final result of the Spirit's work in us is "endless joy in the presence of God, becoming like God, and ... becoming God"" (Jenson 1999:311), and: "Our end is not participation in an abstract essence of Godhead, but in the life that Father, Son and Spirit have among themselves" (Jenson 1996:3). This notion of Jenson is of course very strongly integrated in his understanding of the relation between time and Trinity.

The strong eschatological emphasis of Jenson's theology characterizes it as a theology of hope. Within the Trinity, of who God is, lies our real hope. Or as John Albright (1996:44) said about Jenson's theology: "God's triunity ... is the ground work for real hope." Francis Watson (2002:202) adds to this when he says about Jenson's theology: "God is fully God only at and from the end, and this trinitarian narrative theology is therefore also a theology of hope..."14

\section{It is a Story of Hope}

To summarise the way Jenson is telling the story of God for people today, ${ }^{15}$ is too comprehensive a task for this essay. Therefore I will focus on an example of how Jenson himself summarize important aspects of his theology in a recent article of him, entitled "Second Thoughts about Theologies of Hope" (Jenson 2000b). ${ }^{16}$

Jenson asks the critical question: Can eschatological hope survive Marxist, ecological and other criticism? He answers that it certainly can and that the question should be reversed: Can Marxist and other projections ${ }^{17}$ survive criticism from an authentically eschatological viewpoint? This question brings us to an uncomfortable point in the conversation between the Christian religion and the "theologians of Olympian-Parmenidean

14 It is important to recognize Jenson's theology specifically as a theology of hope, because his theology can in this sense be understood as a reaction to the nihilism of postmodernism. Buckley $(2000: 21)$ says for example

"Jenson's theology might take the question to be a challenge of nihilism the story that things amount to nothing, from which we can abstract a metaphysics focused on "the awaited advent of nothingness," and Jenson (1997b:6) himself wrote: "So, finally, a basic proposition: the church's moral responsibility for the world is to speak in such a way, by audible and visible words, as to combat the world's decline toward nothingness."

15 Jenson (2002:viii) describes these modern people as post-Christians: "Most unbelievers in America and other western countries are post-Christians. They have been baptized and brought up in church, but no longer believe and practice the faith. Hence the need for re-evangelization." And: "For most part, we moderns, who also want to be somehow religious soldier on with abstracted Christianity. That 'we' is to be noted in this connection. To the precise extent that American denominational Christianity missed out on the theological revolutions of the 1920s, and so carries on with modernity's project in the midst of modernity's demise, much of American Christianity has itself become post-Christian. Their theology is a collection of clichéd abstractions ... they could easily make any hero ... the guru of peace-and-justice, instead of Jesus, and sometimes do" (Jenson 2002:28).

16 I specifically decided to choose this article because it clearly indicates the importance of hope in the story of God for us (as told by Jenson) and it helps us to understand certain decisions Jenson has made throughout his theology. It also fits in very well with the context of Jenson's theology that is described up to this point in the essay as a trinitarian narrative and ecumenical theology and of course an eschatological theology.

17 Jenson (1997a:53-55) says about Feuerbach's notion of projection: "What each of the gods does is validate and enforce the particular human situation, with its structure of values, from which she/he/it is projected in all the alienation and tyranny of every situation. Humans thus construct various 'eternities' or gods as embraces around time in their various mythical systems in order to save themselves from temporality, finitude, and death." 
revelation" 18 - the question of which critique trumps? Who settles the question about truth, Socrates or Isaiah? Jenson (2000b:336) says that "despite rhetoric about 'openness' and the like, we have to choose and always do choose, especially when we claim not to." Jenson's conviction is that modernity's dominant theology made the wrong choice in this regard. He says 'modernity's theology was 'mediating' that is, it accepted that Western modernity's wisdom finally trumps. It took modernity's religious and metaphysical prejudices for foundational truth, and it therefore cut its understanding of the gospel to fit them" (Jenson 2000b:336).

In this context Jenson writes his theology as an eschatology. In other words he understands that to speak of the promises and hope of the gospel is something offensive to Western modernity's received wisdom - "it is arguable that the Enlightenment has found precisely the gospel's promises especially indigestible" (Jenson 2000b:336) - and he makes the assertion of the gospel's promises a conscious and decisive criterion of his thinking.

To answer then the specific Marxist critique of Christianity being a pie in the sky by and by, Jenson notes that it depends on whether the promise of the kingdom of God is true or not. This question was not entertained by Marx because it was accepted by him that all metanarratives are founded on interest so that the question of truth does not arise. Jenson (2000b:337) points out that the problem here is one of petitio principii: "the reason the proletarian meta-narrative is suppose to be in good faith when others are not, is that it is the final one. Which since the narrative is eschatological, is the same as to say, because it is the true one."

So there are two sets of eschatological promises here (Marxist and Christian) and both claim to be true and the other false. Why should we think the gospel-promise is a true one? Jenson says because Christ has in fact risen and must therefore make good His claim to be Lord. ${ }^{19}$ And what about the ecological (or cosmological) critique ${ }^{20}$ of biblical eschatology? Jenson's opinion is that this critique has so triumphed in the cultural mind that it is scarcely recognized as a critique of something. He answers this critique more or less in the same way he answers the Marxist critique when he asks the question: "Who after all, has decreed that the narrative spun by current cosmology is the encompassing story of reality, within which room must be found, or not found, for other narratives?" (Jenson 2000b:338). He continues then and says that we must follow the lead of the trinitarian theologian Jonathan Edwards ${ }^{21}$ who "by a non-mechanistic construal of Newton and Locke found room for their

18 Jenson specifically calls them theologians and not philosophers: "We usually refer to the work of Greece's theologians with their own name for it, 'philosophy.' We have thereupon been led to think this must be a different kind of intellectual activity than theology, to which theology perhaps may appeal for foundational purposes or against which theology must perhaps defend itself. But this is a historical illusion; Greek philosophy was simply the theology of the historically particular Olympian-Parmenidean religion, later shared with the wider Mediterranean cultic world" (Jenson 1997a:9-10).

19 Jenson is aware of the post-modern context in which he makes such claims. He (Jenson 2000b:337) says: "An aspect of what is sometimes called 'post-modern' thought is willingness to accept the irreducibility of one's own starting point or points. If we are Christian, it is willingness to take the fact of the resurrection as a warrant also in discourse with those who do not think there is such a fact, and not to suppose that this necessarily terminates mutual intelligibility or persuasion or even resultant change of conviction. The will to unabashed assertion of biblical promises surely partakes of this mood; there is some affinity between at least my sort of 'theology of hope' and certain aspects of post-modern intuition."

20 Jenson (2000b:337) formulates this critique as follow: "The universe, current cosmological speculations propose, is doomed either to fall back from the big bang into a concluding big crunch and singularity, or to thin out indefinitely into what would still be a sort of field but hardly anything like a universe. Or ... there are many parallel universes and new ones can bubble up in the quantum field at any time. In none of these scenarios is there room for events fulfilling the gospel's promises."

21 Jenson follows Jonathan Edward's proposals at critical points of his theology. It is specifically Edwards's 
narrative within the triune narrative" (Jenson 2000b:338). Within this same line of thought Jenson (2000b:339) gives his definition of theology of hope: “...is a biblical theology in the sense that, against the practice of modern theology, it does not think the deliverances of Enlightened religion or of ideological interpretations of scientific procedures or results must always trump, that is does not suppose that truth taught by Aristotle or Newton is more foundational or comprehensive or natural than truth taught by Isaiah or John. And it chooses eschatology as a specific ground to hold, in part because this locus was a chief victim of mediation in the period just behind us."

\section{How will the End then be?}

Jenson's theology of hope asks the question of how the end will really be. He starts his discussion with the question: How is the End related to the Beginning? And Jenson's concern is that "our theology has regularly, if sometimes subliminally, construed the End as a repristination of the beginning" (Jenson 2000b:340). There is an understanding that "God made a world and it was good; but then something went wrong and God undertook restorative measures" (Jenson 2000b:340). ${ }^{22}$ Jenson argues that what is at work here is the wrong understanding of eternity and time - one of the main arguments of his whole theology. He says that the Greeks confused Christian theology because they posited eternity as the sheer negation of time. This implied that eternal being is constituted above all by impassibility, by immunity to the threats and possibilities that time brings. In other words, the future can bring something threatening and therefore the eternal being must be so construed that it would be immune to it. This immunity is the way the Greeks understood eternity: that the gods remain unchanged despite the future. They argued that if we can join the gods we can share some of their immutability. ${ }^{23}$

Jenson cannot accept this 'Greek' definition of eternity, because it would plainly imply for his life story and other stories about life that "the maxim could be true, that in my beginning is my end, and no story at all that wholly neutralized the future's possibilities in advance" (Jenson 2000b:340). He argues that this type of eternity would not do for Christian theology ${ }^{24}$ because the story the Bible tells is truly interesting and it "let hope out

thoughts about the Trinity, the doctrines of creation and the church in which Jenson follows Edwards. In his Systematic Theology Jenson follows Edwards at a critical point in his eschatological thoughts: "We introduced Jonathan Edwards at the exact point where the development began to lead to the present point. And now we may simple appropriate his insight. The 'exquisite spiritual proportion' that will be the eschatonlogical perfection of creation and that is now its inner meaning is, according to Edwards, that of 'a very complex tune, where respect is to be had to the proportion of a great many notes together.' If we try to conceive the Kingdom, the 'society in the highest degree happy,' we should 'think of them ... sweetly singing to each other"' (Jenson 1997a:235). See also in this regard Jenson's book about Edwards' theology: America's Theologian: A Recommendation of Jonathan Edwards. (1988).

22 Jenson (1963:148) says in agreement with Karl Barth: "We must agree in rejecting the commonsense view that the Incarnation was God's second choice in view of the failure of an original plan for a natural perfecting of creation. Quite probably the deeply unchristian slogan which passes universally for piousness: 'I will do the best I can and God will forgive the rest,' has its roots in just the separation of creation and reconciliation which Barth rejects. We must learn to see God's grace in Christ as the point from which we live, not as an emergency help for those occasions when our moral endeavors prove inadequate."

23 Jenson (2000b:340) says: "Eternity as the Greeks construed it is salvific precisely as it supposed to be the guarantee that time's hastenings have no other end than their beginning, that whatever happens on the fields of Troy where time and its hopes are disappointed, the gods remain unchanged."

24 Colin Gunton (1995:948-949) summarizes Jenson's perspective very well on this point: “According to Jenson, religion is the innate human drive to escape our being in time for a timeless realm beyond, and with its eternalizing drive Western Christianity has capitulated to the anti-gospel of timelessness." Gunton (1995:949) continues and discusses Jenson's reaction to this: "In contrast, the Gospel, which speaks of God's radical 
of the box. And then it claims to be about the real world, indeed, first to constitute the real world for our habitation" (Jenson 2000b:340). ${ }^{25}$ Jenson (2000b:341) states his answer clearly: "If the gospel is true, the End is dramatically related to the beginning, or what is the same thing, historically related. God does not create a cosmos, which thereupon is shocked into movement so as to have a history. God creates precisely a history, which is a universe, an intelligible whole, because it has an intended end." 26

So the question is then: What could be an end of history? If we could go into the future to the end, what will we discover there? Will it be that time and discourse had simply stopped (as in the cosmological critique)? Jenson cannot see that anyone would want to get to that point and then he asks if this notion is even intelligible. He argues that since "what God creates is a history, the one conceivable end of history must be again a sublation, now into the only thing left to be taken into, God" (Jenson 2000b:341). And here we hear his trinitarian thoughts and reaction against nihilism clearly: "An end of history, if not a sheer nothing, can only be temporal history's sublation into the infinite history that Father, Son and Holy Spirit are between them" (Jenson 2000b:341). For Jenson, it is plain that "the chains of historical sublation do not make a whole history unless they eventuate in a sublation that is not himself sublated. Thus the doctrine of theosis, the doctrine that our end is inclusion in God's life, is not simply the brand of eschatology preferred by eastern churches; it names the only possible end of creation, the only possible end of being that is history and drama" (2000b:341).

Jenson himself mentions that this theosis can only be said about a God who indeed is himself a history - only of the triune God. The fact that God is thus not immune to time (a history himself), and is trinitarian (the archetype of thesis, antithesis and synthesis), are crucial for Jenson's eschatology. A bad doctrine of Trinity (like Hegel had according to Jenson $)^{27}$ can for example lead to a perception of God as timeless and impassable. This happens if the Father fulfils the definition of God in such a fashion that he could have been God on his own. The problem here is that this "supposition has a kickback: it compels a construal of deity that an isolated 'Father' could indeed instantiate, that is, a construal of deity by beginning rather than the end, by perdurance rather than freedom, by timeless reason rather than history's reason" (Jenson 2000b:342). Jenson tries to change this by putting much more emphasis on the role of the Spirit within the Trinity and links him to the future: "the Spirit unites the Father and the Son in love only in that he is an active agent who intrudes to reconcile them, only in that he is the third party who gives himself to both,

involvement in our time, is encapsulated in the doctrine of the Trinity. There is therefore no spatially conceived transcendence of God and the world, for that leads back to the timeless. Rather, God's transcendence is to be conceived temporally, as one of futurity, expressed by the priority of the doctrine of the Holy Spirit as the goal of the trinitarian history."

25 Jenson's doctrine of creation is connecting God to space and time at the same time. Jenson (1997a:226) says: "Whether or not we wish to call God's 'pure duration' his uncreated 'time', God as Father, Son and Spirit can make room in himself for others, and the room that he makes is our created time. The opening of that room is the act of creation." And in his Systematic Theology he says: "For God to create, we said, is for him to take time for us. But it must surely also be said, that for God to create is for him to make space for us." $\mathrm{He}$ explains: "God does not create spatial objects that thereupon move through time; he creates temporal-spatial objects, that is, in a more precise language, he creates histories" (Jenson 1999:46).

26 Jenson (1999:14) says clearly: "God does not create a world that thereupon has a history; he creates a history that is a world."

27 The problem with Hegel is according to Jenson (2000b:342) that "despite his grandiloquent talk of Geist, he like most Western theology did not make the biblical Spirit's role decisive for his construal of deity. His God, despite all his rhetoric and the insight behind it, is timeless reason, it lacks life, and therefore the sublation of history into his God is after all a return to the beginning and very much like death." 
just and only so freeing them for each other." And: "the Spirit gives himself to us as he does to the Father and the Son, so that in the church we become able to understand freedom and love. With God, and therefore with his creation, the beginning occurs only as it is freed for the end beyond it, and the end occurs only as love for all that already is" (2000b:342).

\section{The Trinity as the God of Hope}

It is clear in Jenson's argument up to this point (and in his whole theology) that the God of hope can only be the Father, Son and Holy Spirit. He says that the biblical God is uniquely identified as Father, Son and Spirit and that as we come to know this specific God we find that he can appropriately be described as a God of hope.

In his explanation of this point we find a good summary of Jenson's trinitarian theology. He says that Father, Son and Spirit are biblical names for the dramatis dei personae that in fact appear in the Bible's telling of God's history with us. The trinitarian relations by which the identities of the three are constituted are slogans for plot lines of this story (for example: the Father begets the Son and the Son is begotten; the Father breathes the Spirit and the Spirit is breathed). The being of this God - as one God - is according to Jenson that he is the life, the history, that occurs between these personae and that has this plot. It is only the three who have this history: "This God simply is the life lived between Jesus and the one he called Father, in the Spirit who liberates them for each other. And of course there is no life or history without hope, without the future's opening of possibility and the courage to meet that future without fear" (Jenson 2000b:343).

An interesting characteristic of this description is that it is about God and not about us. The triune God is in other words not first the triune God as a God of our hope - he does not need us, to be the God of hope, argues Jenson. This 'full of hope' is a predicate that may be conceived as real in God without supposing the existence of creatures. This attribute makes sense not only according to a pattern of argument that is ancient in theology, but it is the great illuminating attribute of God if (according to Jenson) we give the Spirit his biblical due. Therefore, Christian hope is "nothing other than a certain participation in the life of God" (Jenson 2000b:344).

This brings Jenson back to his trinitarian point: "The God who can be full of hope, the triune God, is the Father, Son and Spirit of the story Scripture tells; that is ... he lives his own life as that same history into which he takes us. Thus we come to know him in the way in which we come to know each other, as we live together" (Jenson 2000b:344). In this process we rely on documents and we can of course, at the same time, not deny that God is mystery. Jenson compares this with living with his wife for forty-five years. He knows her but she is still more mysterious daily. This is not a problem for him as it is no problem to say of God that he knows him and "what I know is the mystery of the hope that he is for himself and for me" (Jenson 2000b:344).

So for Jenson it is not a problem to construe our relation to the triune God of hope. We address him and name him to each other when we say for example "Our Father in heaven..." We say that because by baptism and Eucharist we are one with his Son Jesus so that we do in fact live with this Father. Jenson says that, if we think there is a problem here, it is because we are subliminal unitarians. But the real problem is that "a monadic God, whose otherness from us cannot include us, could only be known by laboriously obtained glimpses and named by projections and metaphors pressed from such experience." And: "For with such a God, to say we can only hope in him would be to say he was simply not yet available to us" (Jenson 2000b:344). 


\section{The Alternatives to God being a God of Hope}

For Jenson the only alternative to faith in a God of hope is modern Westerners ${ }^{28}$ faith in sheer lack of hope, that is in nihilism. He says that the post-war prosperity helped them to understand that the advent looming on the horizon is the advent of nothingness, the hour of Nietzsche's last man. And it is because modern Westerners start to fear that Nietzsche was right, that theologians made so much of hope in the last century.

So, what happens when the culture of modern Westerners, whose self-understanding was once based on the gospel, turns against that gospel? Jenson says he has been occupied by this question since the beginning of his career. He explains this question and says that modern Westerners have been taught by Scripture to construe history by its End, in accordance with a final sublimation into an infinite history. So the question is: what happens when those so taught no longer believe there is such an infinite history to be taken into? The answer according to Jenson is that they will then of course see precisely nothing for themselves (and their world) to be finally taken into and all those little sublations that make up their temporal existence will confront them with that void. ${ }^{29}$ Jenson (2000b:345) thus concludes: "Whether actual nihilism is possible is arguable. But life under the shadow of its threatening advent must be possible, since we are living it. This shadow is the apologetic context of at least my sort of "theology of hope.",

Although Jenson succeed in many ways in his 'theology of hope' it is not without problems. The advantages of his "story tellinginclude that it tries to bring hope, that it focuses on eschatology and that it shows the benefits of a narrative trinitarian understanding of God. However, some of the critique against his theology is that it is a quasiHegelian system (Hunsinger, Sholl, Mattes) and that his argument against the timelessness of God is flawed (Burgess, Hart). It thus seems to me that we still need to think a lot more about how the end will really be in order to know how to tell the story.

28 Jenson uses expressions such as "modern Westerners, us, we, our and culture" to refer specifically to American Christianity (as for example in footnote 19). The term 'modern Westerners' thus refers to Christians in the modern American context. It should be kept in mind here that Jenson sees himself as an American theologian and many see him as 'the' Lutheran American theologian.

29 Jenson (2000b:345) says: "In other terms: we bourgeois have wanted a world to live in that is palpable, reliable, coherent and adapted as it is currently fashionable to say to our flourishing. And we have each individually wanted to be the autonomous definers of what constitutes coherence and flourishing. That we cannot have it both ways is in itself apparent; but only after staring long into the emptiness that opens between them we taken fright." 


\section{BIBLIOGRAPHY}

Albright, JR 1996. The Story of the Triune God: Time and Eternity in Robert Jenson's Theology. Christians Scholars Review 26:1, 36-54.

Braaten, CE \& Jenson, RW (eds.) 1984. Christian Dogmatics. Philadelphia: Fortress Press.

Braaten, CE \& Jenson, RW (eds.) 1995. A Map of Twentieth Century Theology. Readings from Karl Barth to Radical Pluralism. Minneapolis: Fortress Press.

Braaten, CE \& Jenson, RW (eds) 1995. Either/Or. The Gospel or Neopaganism. Grand Rapids: WB Eerdmans.

Braaten, CE \& Jenson, RW (eds.) 1995. Reclaiming the Bible for the Church. Grand Rapids: WB Eerdmans.

Braaten, CE \& Jenson, RW (eds.) 1995. The two cities of God: the church's responsibility for the earthly city. Grand Rapids: WB Eerdmans.

Braaten, CE \& Jenson, RW (eds.) 1996. The Catholicity of the Reformation. Grand Rapids: WB Eerdmans.

Braaten, CE \& Jenson, RW (eds.) 2000. Sin, Death, \& the Devil. Grand Rapids: WB Eerdmans.

Braaten, CE \& Jenson, RW (eds.) 2002. The strange New Word of the Gospel. ReEvangelizing in the Postmodern World. Grand Rapids: WB Eerdmans.

Braaten, CE \& Jenson, RW (eds.) 2003. In One Body Through the Cross. The Princeton Proposal for Christian Unity. Grand Rapids: WB Eerdmans.

Braaten, CE \& Jenson, RW (eds.) 2003. Jews and Christians. People of God. Grand Rapids: WB Eerdmans.

Braaten, CE \& Jenson, RW (eds.) 2004. The Ecumenical Future. Grand Rapids: WB Eerdmans.

Buckley, JJ 2000. Intimacy: The Character of Robert Jenson's Theology. In: Gunton, CE (ed.) 2000. Trinity, Time, and Church. A Response to the Theology of Robert W Jenson, 10-22. Grand Rapids: WB Eerdmans.

Burgess, A 2004. The Ascension in Karl Barth. Burlington: Ashgate.

Carey, P 1999. Book reviews. Scottish Journal of Theology 52:1, 133-135.

Ford, DF (ed.) 1989. The Modern Theologians. An Introduction to Christian theology in the twentieth century. Oxford: Blackwell.

Forde, GO 2000. Robert Jenson's Soteriology. In: Gunton, CE (ed.) 2000. Trinity, Time, and Church. A Response to the Theology of Robert W Jenson. 126-138. Grand Rapids: WB Eerdmans.

Gunton, CE 1995. The Twentieth Century. In: Byrne, P \& Houlden, L 1995. Companion Encyclopedia of Theology. 946-957. London: Routledge.

Gunton, CE (ed.) 2000. Trinity, Time, and Church. A Response to the Theology of Robert $W$ Jenson. Grand Rapids: WB Eerdmans.

Hart, DB 2003. The beauty of the infinite: the aesthetics of Christian truth. Grand Rapids: WB Eerdmans.

Hunsinger, H 2002. Robert Jenson's Systematic Theology: a review essay. Scottish Journal of Theology 55:2, 161-200.

Jenson, RW 1963. Alpha and Omega: A Study in the Theology of Karl Barth. New York: Thomas Nelson.

Jenson, RW 1969. God after God. The God of the Past and the God of the Future, Seen in the Work of Karl Barth. Indianapolis: Bobs-Merrill. 
Jenson, RW 1973. Story and Promise: A Brief Theology of the Gospel about Jesus. Philadelphia: Fortress Press.

Jenson, RW 1982. Triune Identity: God According to the Gospel. Philadelphia: Fortress Press.

Jenson, RW 1988. America's Theologian: A Recommodation of Jonathan Edwards. New York: Oxford University Press.

Jenson, RW 1989. Karl Barth. In: Ford, DF (ed.) 1989. The Modern Theologians. An Introduction to Christian theology in the twentieth century, 23-49. Oxford: Blackwell.

Jenson, RW 1992. Unbaptized God. The Basic flaw in Ecumenical Theology. Minneapolis: Fortress Press.

Jenson, RW 1995. Essays in Theology and Culture. Grand Rapids: WB Eerdmans.

Jenson, RW 1996. The Church as Communio. In: Braaten, CE \& Jenson, RW (eds.) 1996. The Catholicity of the Reformation, 1-12. Grand Rapids: WB Eerdmans.

Jenson, RW 1997a. Systematic Theology, Volume 1: The Triune God. Oxford: Oxford University Press.

Jenson, RW 1997b. The Church's Responsibilty for the World. In: Braaten, CE \& Jenson, RW (eds) 1997. The two cities of God: the church's responsibility for the earthly city, 1-11. Grand Rapids: WB Eerdmans.

Jenson, RW 1999. Systematic Theology, Volume 2: The Works of God. Oxford: Oxford University Press.

Jenson, RW 2000a. Can we have a story? First Things 101, 16-17.

Jenson, RW 2000b. Second Thoughts about Theologies of Hope. Evangelical Quarterly, 72:4, 335-346.

Jenson, RW 2002. What is a Post-Christian? In: Braaten, CE \& Jenson, RW (eds.) 2002. The strange New Word of the Gospel. Re-Evangelizing in the Postmodern World, viiviii, 21-31. Grand Rapids: WB Eerdmans.

Jenson, RW 2003. On Thinking the Human. Resolutions of Difficult Notions. Grand Rapids: WB Eerdmans.

Mannermaa, T 2000. Doctrine of Justification and Trinitarian Ontology. In: Gunton, CE (ed.) 2000. Trinity, Time, and Church. A Response to the Theology of Robert W Jenson, 139-145. Grand Rapids: WB Eerdmans.

Mattes, MC 2000. An Analysis and Assessment of Robert Jenson's Systematic Theology. Lutheran Quarterly 14:4, 463-494.

Peters, T 1998. God Happens: The timeliness of the Triune God. The Christian Century 115:1, 342-344.

Sholl, BK 2002. On Robert Jenson's Trinitarian Thought. Modern Theology 18:1, 27-36.

Soulen, RK 1999. YHWH the Triune God. Modern Theology 15:1, 25-54.

Watson, F 2002. “America's theologian”: an appreciation of Robert Jenson's Systematic Theology, with some remarks about the bible. Scottish Journal of Theology 55:2, 201224.

Yeago, DS 1992. Catholicity, Nihilism and the God of the Gospel: Reflections of the Theology of Robert W Jenson. dialog 31, 18-22. 